\title{
DIVERSIFICATION OF THE PEASANTS' RATIONALITY AS STREET VENDORS IN JUNREJO, BATU CITY
}

\author{
Aditya Danan Rosyidin \\ The author is sociology teacher at SMAN 2 Batu. \\ E-mail: aditongisnadeutab@gmail.com
}

\begin{abstract}
Abstrak
Dalam rentang tahun 2009 sampai 2013 produksi pertanian di Kota Batu mengalami penurunan. Dampak penurunan pertanian ini menjadikan buruh tani kesulitan secara ekonomi. Hal ini menjadikan adanya buruh tani yang mulai meninggalkan aktivitas bertaninya. Fenomena tersebut menjadikan adanya diversifikasi rasionalitas pekerjaan buruh tani menjadi PKL. Tujuan dari penelitian ini adalah untuk mendeskripsikan skema tindakan voluntaristik para pekerja buruh tani dalam mencapai kebutuhan ekonominya pada sektor pedagang kaki lima, serta untuk mendeskripsikan rasionalitas diversifikasi pekerjaan buruh tani menjadi pedagang kaki lima di Kecamatan Junrejo Kota Batu.

Penelitian ini menggunakan pendekatan kualitatif dengan tipe deskriptif. Subyek penelitian adalah buruh tani yang memilih untuk meninggalkan pekerjaan sebagai buruh tani untuk beralih menjadi PKL dan buruh tani yang masih tetap menjadi buruh tani tetapi juga bekerja sebagai PKL. Teknik pengumpulan data menggunakan observasi, wawancara dan dokumentasi. Sedangkan teknik analisa data menggunakan reduksi data, kategorisasi data, sintesisasi. Teknik pemeriksaan keabsahan data menggunakan persistent observation, triangulasi dan peerderieting.

Hasil dari penelitian ini adalah skema tindakan voluntaristik pekerja buruh tani dalam mencapai kebutuhan ekonominya pada sektor PKL bermula dari pesatnya pariwisata di Kota Batu. Pekerja buruh tani memiliki tindakan terhadap lesunya pertanian dengan memanfaatkan perkembangan pariwisata di Kota Batu. Beberapa tindakannya adalah menjadi PKL di kawasan Alun-alun Kota Batu, membuka usaha lain dan menjadi driver online. Salah satu tindakan rasional buruh tani adalah melakukan diversifikasi pekerjaan. Buruh tani dalam melakukan diversifikasi pekerjaan didasarkan atas pertimbangan pekerjaan buruh tani yang sangat berat dan penghasilan yang sedikit. Tujuan buruh tani dalam melakukan diversifikasi pekerjaan adalah untuk memperoleh keuntungan yang lebih besar dibandingkan dengan pekerjaan buruh tani.
\end{abstract}

Kata Kunci: buruh tani, diversifikasi, PKL, rasionalitas, voluntaristik

\begin{abstract}
In the range of 2009 to 2013, agricultural production in Batu City declined. The impact of this decline in agriculture has made farm labor economically difficult. This makes the farm laborers begin to abandon their fighting activities. This phenomenon
\end{abstract}


makes the diversification of the rationality of the work of farm labors into street vendors. The purpose of this study was to describe the scheme of voluntaristic action of farm laborers in achieving their economic needs in the street vendor sector, as well as to describe the rationality of the diversification of farm laborers' jobs into street vendors in the Junrejo District of Batu City.

This study uses a qualitative approach with descriptive type. The subjects of the study were farm laborers who chose to leave work as farm laborers to turn into street vendors and farm laborers who still remained farm laborers but also worked as street vendors. The technique of collecting data uses observation, interviews, and documentation, while the data analysis technique uses data reduction, data categorization, synthesis. The technique of checking the validity of the data uses persistent observation, triangulation, and peerderieting.

The results of this study are that the scheme of voluntaristic action of farm laborers in achieving their economic needs in the street vendors sector starts from the rapid tourism in Batu City. Farm workers have actions towards sluggish agriculture by utilizing the development of tourism in Batu City. Some of their actions were to become street vendors in the Batu City Square area, open another business and become an online driver. One of the rational actions of farm workers is to diversify work. Farmers in diversifying their work are based on consideration of the work of farm labors who are very heavy and have little income. The aim of farm workers in diversifying their work is to obtain greater profits compared to the work of farm workers.

Keywords: diversification, farm laborers, rationality, street vendors, and voluntary.

\section{Introduction}

Nowadays, there is undoubted that Batu City is synonymous with tourist cities. However, long before Batu City had become a tourist city like today, this city is a city that is identical with apple-producing regions, in which apple plants began to be cultivated in the 1930s. Based on stories from local residents in the Bumiaji area, the apple was actually brought by the Dutch at that time and tried to be cultivated in the Bumiaji. This is based on soil conditions that might be suitable for producing the apple plants. The types of apples that were developed at that time were Manalagi, Room Beauty, Ana, and Australian plants. In the 1990s a new type of apple was also developed that it is a crossing between manalagi apple and ana apple called as wangli apple. As time goes by, apples also grew in Batu city, and in the 1980s apple production experienced a heyday. From the recording of the Batu Agriculture and Forestry Service Office, the total area of apple trees in 1980 was 2,015 hectares with annual production of 72,000 tons from 5.64 million trees (regional.kompas.com/ edition April 7, 2011). This identifies that agriculture in Batu City was once the beloved economic community.

In general, in the range of 2009 to 2013 , agricultural production in Batu declined as found in such of vegetable and apple plants. This is certainly due to several factors such the uncertain climate conditions, the imbalance 
between production prices and selling prices, and the reduced agricultural lands that were caused by the development of tourism. This triggered a decline in agricultural production over there. So far, Batu City Government has several programs to boost agricultural productions, one of them is the agricultural program namely "go organic".

It is more interesting that Batu City Government has the agricultural program that is basically good because not only is running the movement - "go organic", but also providing the seeds for agriculture. Nonetheless, implementation in the field is certainly not as good as the program that has been planned. In Monday edition of Surya Daily, 8 December 2014, Sulkan stated that the farmer groups he had participated in received an agricultural seeds' stock from the Batu City Government. Conversely, he and his colleagues never got the seeds which were supply from the government. This indicates the agricultural program in this region is still not optimal in terms of its implementation.

Therefore, there are several problems as follows: less optimal agricultural programs, many farmers in entangled in debt, uncertain climate conditions and globalization impacts on farmers helpless for improving their economic lives. According to Wahyudi, the farmer is a powerless social class, so his bargaining position is weak (2005: 273). Unfortunately, even poverty begin to hit the area of Batu. In 2010, Kota Batu's budget reached Rp. 371 billion was apparently unable to eradicate poverty. In accordance with the latest data held by the Central Statistics Agency (Badan Pusat Statistik BPS), the number of poor households (Rumah Tangga Miskin-RTM) in Batu reached 12.2 percent, equivalent to 5,817 households. When detailed, from the three sub-districts in the tourist city, Junrejo had the highest poverty rate from two other sub-districts, namely Batu and Bumiaji. The number of poor households in Junrejo reached 16.69 percent, while Bumiaji and Batu were at 11.07 percent and 10.44 percent respectively (http://www.simpuldemokrasi.com/titiktitik-kemiskin-kota-batu-masih-tinggi.html: accessed on November 20, 2014, at 01.10 p.m).

Initially, peasants depended on their lives from the agricultural sector beginning to leave their farming activities. Hence, the rapid development of tourism in Batu City has made it difficult for farmers to adapt to existing changes. Uniquely, the rampant development of the tourism industry in this area, which has shifted agrarian life to tourism, did not create a resistance movement by farm labors, and they actually leave their jobs as farmers. From the data of BPS between 2003 and 2013, there had been a decline in Agricultural Households (Rumah Tangga Pertanian - RTP). This is explained in the following table: 
Table 1.1. Agricultural Households from 2003 to 2013

\begin{tabular}{clrc}
\hline No. & Sub-Districts & $\mathbf{2 0 0 3}$ & $\mathbf{2 0 1 3}$ \\
\hline 1. & Batu & 6.174 & 4.833 \\
\hline 2. & Junrejo & 4.856 & 3.982 \\
\hline 3. & Bumiaji & 8.296 & 8.542 \\
\hline & Batu City & 19.326 & 17.357 \\
\hline
\end{tabular}

Source: BPS of Batu City, 2013 (batukota.bps.go.id)

Based on the table above it can be explained that there had been a decrease in agricultural activities between 2003 and 2013, from 19,326 to 17,357 . In addition, It means that for the decline in agricultural households during the period, each year decreased by $1.07 \%$ (batukota.bps.go.id: accessed on December 28, 2106)

The decline is also caused by destruction in agricultural land as it is not profitable for the economy of the community, in order for it carries out the community selling agricultural land used as tourism support facilities, such as villas, inns, and homestays. Based on data from the Batu City agricultural service in 2014, there was a decline in agricultural land in the period 2008 to 2013. In 2008 the area of paddy and non-paddy fields amounted to 6679.57 , then decreased to 6503.09 in 2013. This indication will certainly result in a decrease in employment in the agricultural sector.

Agricultural land degradation is in line with the rapid tourism in Batu City. This encourages the peasants to have jobs other than working in the agricultural sector. The structure of the business sector for Batu's people has shifted from Agriculture, Forestry, and Fisheries to other economic sectors. This can be seen from the magnitude of the role of each business field to the total of Gross Regional Domestic Product (GRDP). The biggest contribution in 2015 was generated by the business sector in the category of Large Trade and Retail and Car Repair by 17.85 percent, and then the category of Agriculture, Forestry and Fisheries amounted to 16.30 percent, whereas the other services reached 15.43 percent as well as the provision of accommodation and drinking-food reached at 11.73 , and the Construction was 11.28 percent (GRDP of Batu City during the period 2011-2015, 2016: 49). Hence, the community has paid an opportunity that sectors other than agriculture, especially trade can have an impact on the economy, while the work of farmworkers began to be diverted into the trade sector.

The rapid tourism in Batu had brought farm laborers starting to leave the agricultural sector. According to the data of BPS, there had been an increase from 2012 to 2014 regarding residents working according to employment status. Changes occurred in the main employment status of the self-employed sector as assisted by temporary workers. This circumstance can be explained in the following table: 
Table 1.2. Population Working Based on Job Status, 2012 - 2014

\begin{tabular}{lrrr}
\hline \multicolumn{1}{c}{ Main Jobs's Status } & $\mathbf{2 0 1 2}$ & $\mathbf{2 0 1 3}$ & \multicolumn{1}{c}{$\mathbf{2 0 1 4}$} \\
\hline Self-owned business & 13.732 & 16.289 & 16.337 \\
\hline Self-owned business assisted by temporary workers & 11.466 & 11.685 & 12.419 \\
\hline Self-owned business with the permanent workers & 4.760 & 5.580 & 5.175 \\
\hline Workers/employees/Employee & 39.367 & 37.777 & 36.911 \\
\hline Free worker of Agriculture & 7.442 & 5.669 & 9.383 \\
\hline Non-free workers of Agriculture & 7.988 & 10.616 & 10.858 \\
\hline Unpaid workers & 13.506 & 13.723 & 13.094 \\
\hline
\end{tabular}

Source: Sakernas of Batu, 2014

Looking at the table above, there was an increase in the main employment status sectors where self-employment increased from 2012 to $2014,13,732$ to 16,337 . This implies that employment in the agricultural sector was increasingly being abandoned, due to communities decided to take advantage of tourism by working in other sectors.

Farmers and peasants whose have a slight land is more likely to work in the informal economy in order that it carries out the peasants no longer depend on the economic sector for the owners of agricultural land. They prefer to work in the informal economy because they find it easier to get income from. Moreover, nowadays Batu City has become a tourist destination from both national and international tourists. This change is used by farm labors to switch professions to the informal economy in the midst of the surge in tourism. The condition is in line with the GRDP per capita according to the business field which shows that the trading business field has a greater value than it. Basically, one indicator of the people's welfare development is measured by the amount of GRDP and income per capita, namely to know the extent to which the value added from various economic activities can be enjoyed by each population (GRDP of Batu, 2011-2015, 2016: 53). The following is a table about the GRDP per capita based on the business fields in the range of 2010 to 2015.

Based on the table 3 , in the period from 2011 to 2015 , the GRDP income per capita in the trade sector has always been higher than the agricultural sector.

It further emphasizes that the direction of development in Batu City is no longer centered on agriculture, but rather on the tourism sector. Tourism and agriculture should go hand in hand so that farm labors continue to work in the agricultural sector. In fact, peasants prefer to work in the informal economy with fluctuating income. For this, it is very interesting to study "Diversification of the Peasants' Rationality to Street Vendors (Pedangan Kaki Lima - PKL) in Junrejo, Batu City".

Based on the explanation, there are two formulations of the problems described in the discussion. The first discussion of the problem is about the scheme of voluntaristic 
Table 1.3. GRDP Per Capita by Business Fields (Million Rp), 2010-2015

\begin{tabular}{|c|c|c|c|c|c|c|c|}
\hline \multicolumn{2}{|r|}{ Lapangan Usaha/Industry } & \multirow{2}{*}{2010} & \multirow{2}{*}{2011} & \multirow{2}{*}{2012} & \multirow{2}{*}{ (5) } & \multirow{2}{*}{$2014^{* *}$} & \multirow{2}{*}{$2015 * * *$} \\
\hline & (1) & & & & & & \\
\hline A & $\begin{array}{l}\text { Pertanian, Kehutanan, dan Perikanan/Agriculture, } \\
\text { Forestry and Fishing }\end{array}$ & 5,80 & 6,50 & 7,00 & 7,50 & 8,50 & 9,4 \\
\hline B & Pertambangan dan Penggalian/Mining and Quarrying & 0,10 & 0,10 & 0,10 & 0,10 & 0,10 & 0,11 \\
\hline C & Industri Pengolahan/Manufacturing & 1,50 & 1,70 & 1,80 & 2,10 & 2,40 & 2,68 \\
\hline D & Pengadaan Listrik dan Gas/Electricity and Gas & - & - & - & - & - & - \\
\hline $\mathbf{E}$ & $\begin{array}{l}\text { Pengadaan Air, Pengelolaan Sampah, Limbah dan } \\
\text { Daur Ulang/Water supply, Sewerage, Waste } \\
\text { Management and Remediation Activities }\end{array}$ & 0,10 & 0,10 & 0,10 & 0,10 & 0,10 & 0,1 \\
\hline $\mathbf{F}$ & Konstruksi/Construction & 3,00 & 3,40 & 4,00 & 4,70 & 5,60 & 6,48 \\
\hline G & $\begin{array}{l}\text { Perdagangan Besar dan Eceran; Reparasi Mobil dan } \\
\text { Sepeda Motor/Wholesale and Retail Trade; Repair of } \\
\text { Motor Vehicles and Motorcycles }\end{array}$ & 6,00 & 6,90 & 7,70 & 8,80 & 9,50 & 10,25 \\
\hline $\mathbf{H}$ & $\begin{array}{l}\text { Transportasi dan Pergudangan/Transportation and } \\
\text { Storage }\end{array}$ & 0,40 & 0,50 & 0,50 & 0,60 & 0,70 & 0,75 \\
\hline I & $\begin{array}{l}\text { Penyediaan Akomodasi dan Makan } \\
\text { Minum/Accommodation and Food Service Activities }\end{array}$ & 3,20 & 3,70 & 4,10 & 4,90 & 5,80 & 6,73 \\
\hline J & $\begin{array}{l}\text { Informasi dan Komunikasi/Information and } \\
\text { Communication }\end{array}$ & 2,30 & 2,50 & 2,80 & 3,10 & 3,30 & 3,64 \\
\hline K & $\begin{array}{l}\text { Jasa Keuangan dan Asuransi/Financial and Insurance } \\
\text { Activities }\end{array}$ & 1,20 & 1,30 & 1,50 & 1,80 & 2,00 & 2,33 \\
\hline L & Real Estat/Real Estate Activities & 0,90 & 1,00 & 1,20 & 1,40 & 1,50 & 1,68 \\
\hline $\mathrm{M}, \mathrm{N}$ & Jasa Perusahaan/Business Activities & 0,20 & 0,20 & 0,20 & 0,20 & 0,30 & 0,28 \\
\hline 0 & $\begin{array}{l}\text { Administrasi Pemerintahan, Pertahanan dan Jaminan } \\
\text { Sosial Wajib/Public Administration and Defence; } \\
\text { Compulsory Social Security }\end{array}$ & 1,00 & 1,10 & 1,20 & 1,30 & 1,30 & 1,41 \\
\hline $\mathbf{P}$ & Jasa Pendidikan/Education & 1,30 & 1,40 & 1,60 & 1,90 & 2,10 & 2,27 \\
\hline Q & $\begin{array}{l}\text { Jasa Kesehatan dan Kegiatan Sosial/Human Health } \\
\text { and Social Work Activities }\end{array}$ & 0,20 & 0,30 & 0,30 & 0,40 & 0,40 & 0,46 \\
\hline$R, S, T, U$ & Jasa lainnya/Other Services Activities & 5,70 & 6,20 & 6,60 & 7,10 & 8,00 & 8,86 \\
\hline & 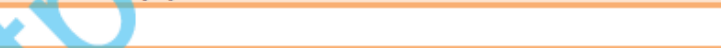 & & & & & & \\
\hline $\begin{array}{l}\text { Produk } \\
\text { Product }\end{array}$ & omestik Regional Bruto/Gross Regional Domestic & 32,80 & 36,8 & 40,7 & 45,7 & 51,6 & 57,4 \\
\hline 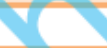 & & & & & & & \\
\hline *Angkc & 的 & & & & & & \\
\hline
\end{tabular}

Source: Gross Regional Domestic Product of Batu, 2011 - 2015

actions of peasants in achieving their economic needs in the street vendor sector in Junrejo, Batu City. The second discussion of the problem is diversification of the peasant's rationality into street vendors in Junrejo, Batu City. The purpose of this study is to describe the scheme of voluntaristic action of farm labors in reaching their economic needs in the street vendor sector, as well as to describe the diversification of the peasant's rationality to street vendors in Junrejo, Batu City.

\section{Research methods}

The research uses a qualitative approach that is also more explorative about social behaviors observed. This is as stated by Mason that "qualitative 
research is characteristically exploratory, fluid and flexible, data-driven and contextsensitive", (2002: 24). This phenomenon is a circumstance that is easier to describe in the form of written words from the people who diversify economic rationality. In addition, the phenomenon is a series of observable community behaviors.

This research was conducted out in Batu City Square and Jalan Sultan Agung area. Some of the reasons have been in a base for the selection of research sites. First, because Batu City Square and Jalan Sultan Agung are areas that are mostly occupied by street vendors. Second, there are many street vendors from the Batu City Square and Jalan Sultan Agung area from the peasants. Third, the Batu City Square is an area that is consistently occupied by street vendors to carry out their economic activities, although they are occasionally disbanded by the Civil Service Police Unit of Batu (Satpol PP Batu).

In addition, the location of the study is also in Junrejo, Batu City. This is based on the decreasing number of agricultural households in which it certainly indicates a diversification of peasants' rationality in the informal economy. This would be in accordance with the research problem, namely the diversification of the peasants' rationality to street vendors in Junrejo, Batu City. The subjects of this study were peasants who chose to leave work as farm labors to switch to street vendors and peasants where they are still working at both as labors and as street vendors.
Data collection in this study uses observation techniques, interviews, and documentation. The observation technique was carried out in order to obtain data relating to the process of diversifying the peasants' rationality into street vendors in Junrejo, Batu City. The techniques of interview use a depth interview so that interviewers can explore data in depth from respondents. This technique was carried out in order to obtain data on the scheme of voluntaristic action of the peasant in achieving their economic needs in the street vendor sector in Junrejo and the diversification of the peasants' rationality into street vendors in Junrejo. Interviews were conducted freely and did not use the interview guide. The researcher would interview directly to farm labors so that the data can be obtained in detail. The documentation is in the form of documents about curriculum vitae of farm labors in Junrejo as well as statistical data on the Batu City's population from BPS.

After the data collected through observation, interviews, and documentation, the data will be analyzed in which the analysis technique uses the fixed comparison method. In general, the process of data analysis includes data reduction, data categorization, and synthesis. The collected data in the form of interviews, observations and documents will be categorized based on the issues discussed. After that, the next step is the data associated with the concepts and theories used in the discussion. 


\section{Results}

1. Scheme of peasant's voluntaristic action in achieving the economic needs in the street vendor sector in Junrejo, Batu City.

The rapid tourism development in Batu has had a socio-economic impact on the community. The development of tourism in the increasingly aggravating city of Batu seems to degrade the identity of Batu City as a farming city. Lots of vacant lands that have turned into concrete hotels and tourist attractions. This is certainly a serious shift in the field of work in society as farming land which is getting less and the high cost of agriculture makes the people involved in agriculture will plan and implement alternative actions on their fields of work.

A large number of tourists visiting the free tourist area of Batu City Square carries out some farm workers no longer depend on the economy in the agricultural sector. They prefer to switch professions into street vendors in the Batu City Square area. This is as stated by Amin as the street vendor in Batu City Square as follows:

"Sakjeke Batu dadi kota wisata, aku wes jarang rewang nang sawah mas. Aku mulai dodolan dek alun-alun mulai tahun 2013, pas bojoku mbobot anak pertama. Waktu iku ono sing nawari aku stan di alun-alun. Terus tak jupuk. Akhire aku dodolan cilok ndek alun-alun sampek saiki. Nek aku ngandalno buruh tani gak cukup mas gawe bendinone, opo maneh waktu iku bojoku meteng. Nek aku dodolan ndek alun-alun iku bendino mesti ono hasile".

"Since Batu became a tourist city, I have rarely become farm labor in the paddy fields. I started selling in the square in 2013 when my wife got pregnant with our first child. At that time someone offered me a booth in the square. Then I take it. Finally, I sold cilok food in the place until now. If I rely on farm labors it is not enough for our daily needs, especially when my wife was pregnant. If I sell in the square every day there must be a result “. (pen)

The developing tourism encourages farm labors that have made the tourism sector to be new jobs. Those switch professions to become street vendors in Batu City Square area.

A very rapid economic change in Batu City has made some people should determine various ways to meet economic needs. Batu City once triumphed with its agriculture in the era of the 90s, whilst at the present, the Batu City agriculture is declining on the 
one side and the growth of tourism is increasing on the other hand. However, this certainly has an impact on the farm labors where those depend on the agricultural sector must find ways to survive apart from it. Mr. Sabar is one of the street vendors in the Batu City Square area who works in three sectors at once. Mr. Sabar stated as follows:

"Since the Wastra Indah factory went bankrupt, I was then helping parents by joining people working in other people's fields. It is also labor and the salary is not okay. If workers' salaries are also seasonal, its mean we are paid when we harvest. As long as I felt it was not enough if this farming labor was made daily income. Moreover, I was married young, graduated from high school immediately married. Finally, I swerved the sale of shirts and sandals on Jalan Kartini. Alhamdulillah, the income from selling this shirt was enough for our daily needs. Saiki mbatu nggak ono sepine mas (now Batu City is never empty of visitors. Pen). Besides that, at my house, I also open a shop, which seller is my wife. I am also a Go-Jek Driver, hehehe. Many of them are street vendors that work besides selling, and they are an online driver in the morning or afternoon. "

The weak agricultural sector has made many farm labors to take advantage of the rapid conditions of tourism and the service sector to meet their daily needs. In fulfilling daily needs, street vendors do not only depend on one sector. Currently, there are street vendors who are the online driver for their daily supplementary income.

2. The diversification of peasant's rationality into street vendors in Junrejo, Batu City

a. Income Preferences Peasants in diversifying the work into street vendors consist of some reasonable aspects, one of them is based on the small preferences of peasant income that can no longer fulfill their daily needs. This is as stated by Amin as follows:

"Nek aku ngandalno buruh tani gak cukup mas gawe bendinone, opo maneh waktu iku bojoku meteng. Nek aku dodolan ndek alun-alun iku bendino mesti ono hasile".

"If I rely on farm labors, it is not enough for our daily needs, especially when my wife is pregnant. If I sell in the square every day there must be a result “. (pen) 
The income preferences make farm labors to switch professions to be street vendors because income from street vendors can be obtained every day.

b. The preference for the heavy work as farm workers

Batu City Square which is never empty of visitors became a place for street vendors to sell their wares. The job of street vendors who do not need physical labor is a lot of consideration for farm workers to switch professions to street vendors. This is as stated by Ms. Susmiati as follows:

"Buruh tani gak ono hasile mas, wes kepanasan, soro, hasile sedino mek telung puluh lime ewu."

"The farm laborers have no results, bro, already overheated and miserable, but the income is only Rp. 35,000 every day, -." (pen)

The work of farmworkers must deal with very hot weather in the fields. This is what makes one of the considerations of farm workers in Batu City begin to move to other professions such as street vendors.

c. Preference for the number of visitors at Batu City Square

Farmers who become street vendors do have many preferences to continue selling in Batu City Square. One of them is the number of visitors in Batu City Square. This is as stated by Pak Sabar as follows:

"Saiki mbatu nggak ono sepine mas (now Batu City is never empty from visitors." (Pen)

Since Batu City became a tourist city, many tourists have been visiting Batu City Square. The number of tourists will certainly also generate profits to street vendors who sell their wares over there.

d. Preference for work efficiency

The amount of available time is used by the community to diversify jobs. The existence of jobs, that are not tied up like the online driver, carries out the people who do two jobs at once, as street vendors and as go-jek drivers. This is as said by Angga Setiawan as follows:

"Apart from that, since the existence of online driver, I have listed additional income. Many of my friends are also like the online driver. Usually, I am driving my child going to school and then continuing to pick up passengers. In other words, my wife's merchandise is prepared at home and if I have finished driving in the afternoon, I can immediately sell it in the square." 
The efficiency of street vendors induces this business actor could diversify their working. The existence of jobs that can be carried out flexibly such as an online driver (Go-Jek) makes the job of street vendors can be diversified into the online driver.

\section{Discussion}

1. Scheme of voluntaristic action of peasants in achieving their economic needs in the sector of street vendors in Junrejo, Batu City

The peasants have an action against the sluggishness of agriculture by utilizing the development of tourism that is stretching in Batu City, some of its actions are to become the street vendors in the Batu City Square area, open another business and become an online driver. Talcott Parsons in his action theory reveals that the individual's ability conducts an act that means determining the means or tools of a number of alternatives available in order to achieve its goal. In his action theory, Parsons said that:

"In contemporary societies, the action is more likely to be rational, which is to achieve a goal or target with the most appropriate means".

In essence, this action theory illustrates that in action, modern society is more likely to be rational that it determines how to achieve its objectives. No individual acts without having a specific goal (Susilo, 2008: 114).

Farm labors have determined ways with rational considerations to reach their goals where they determine how to become street vendors, open other businesses and become the online driver. This can be explained in the scheme of voluntaristic actions of farm laborers in achieving their economic needs as follows:

\section{Chart 1.1 Scheme of voluntaristic action for farmer workers in achieving economic needs}

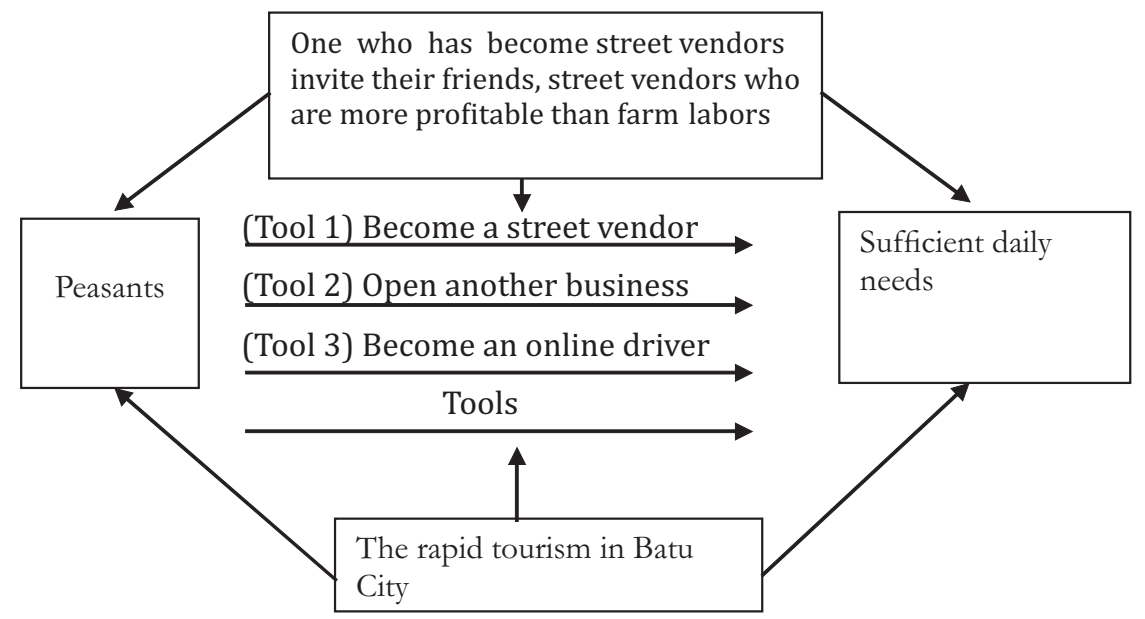

Processed according to Parsons's chart in Turner: 1998; 30 
Based on the chart above, farm labors determine the means or tools to achieve their goals, which are sufficient for their daily needs. This is rooted at the values or norms that develop among farm labors, namely the difficulty of working in the agricultural sector both physically and non-physically, whereas the situational conditions that influence the actions of farm labors to diversify their jobs are the rapid tourism in Batu City.

2. Diversification of peasant's rationality to street vendors in Junrejo, Batu City The rational choice theory of James Coleman can be used to analyze the rationality of the diversification of farm labors' work. The view of rational choice theory assumes that the actor will set goals with their preferences. Some basic assumptions of rational choice theory can be described as follows: (1) Individuals are goal-oriented, (2) Individuals have a hierarchical set of preferences, and (3) In making choices, individuals make rational judgments based on behavior that refers to the hierarchy of preferences, risks in each preference, and the best way to maximize choices (Turner, 1998: 304). Basically, rational choice theory emphasizes more on an actor/ individual who shapes the goals based on rational preferences.
(1) Goal-oriented Individuals

Individual actions are goal oriented. Humans are purposive and goal oriented (Turner, 1991: 354). The actions of farm workers that diversify their work are a manifestation of goal-oriented individual actions. The diversification of farm workers' job has a goal to be achieved. The aim of farm workers in diversifying their work is to obtain greater profits compared to the work of farmworkers and to fulfill their daily needs.

(2) Individuals have a hierarchical set of preferences

Diversification of peasant' jobs in the informal sector is based on several preferences. Humans have sets of hierarchically ordered preferences, or utilities (Turner, 1991: 354). The diversification of work carried out by farm workers is based on several preferences, some of the preferences for diversification of farm labors' jobs in the informal economy include income preferences, preference for the weight of peasant' preferences, the preference of many visitors in the Batu City Square, and work efficiency preferences. Several of these have encouraged peasants to diversify their work in the informal sector, such as street vendors and online drivers.

(3) In making choices, individuals make rational considerations based on: 
- The risk in each preference

Some of the farm workers' preferences in diversifying their work in the informal sector are income preferences, consisting of the preference for the weight of the farm workers, the preference of many visitors in the Batu City Square, and work efficiency preferences. Peasants in determining preferences have considered the risks of these preferences rationally. The risks wondered by farm workers have been carefully considered. Income preferences have risks in the form of uncertain income from street vendors. Meanwhile, farm workers are ready for the situation of income flexibility from street vendors in which they experience that being street vendors always earns income directly every day.

The risk of the preference for the heavy work of farming has also been carefully considered by farm laborers. The risk of farm workers who have a heavy level of work makes farm labors preferring to become street vendors. The work of farm workers in the hot sun and the rain brings the farm workers to choose the risk of work that is not burdensome. This makes peasant diversify their work for being street vendors.

The risk of the preference for many visitors in the Batu City Square area is the lack of visitors at Batu City Square. At risk when there is a decrease in visitors, farm workers have prepared various other alternative jobs as those will innovate the products they sell at Batu City Square. This made visitors more comfortable in the streets and culinary tours in Batu City Square.

- The best way to maximize choice Peasants have chosen to diversify their work to become street vendors in the Batu City Square. The best way to maximize the choice of those become street vendors that is to join the Street Vendors association in Batu City Square. This is done so that farm workers who became street vendors could be registered as traders in the Batu City Square. If an eviction occurs by the authorities, the farm laborers have protection under the association. This is a way for farm workers to maximize employment choices for becoming street vendors.

\section{Conclusion}

The voluntaristic action scheme of peasants in achieving their economic needs in the street vendor sector stems from the rapid tourism in Batu City. Many of the vacant lands which have turned into concrete hotels and tourist attractions make a shift in the field of work in the community. The community involved in agriculture will plan and carry out alternative actions in the field of work. The tourism sector is used by farm labors as an alternative to meet their daily 
needs. This is based on enormous profits in the tourism sector. In this regard, farm labors have an action against the sluggishness of agriculture by utilizing the development of tourism that is being stretched in Batu City. Some of their actions are to become street vendors in the Batu City Square area, open another business and become an online driver.

Peasants will act rationally to fulfill their daily needs in which one of the rational actions of farm labors is to diversify the work. They in diversifying their work are based on certain considerations. The work of farm workers is very heavy because the low income that brings out them is not made the foundation of the economy. The aim of farm workers in diversifying their work is to obtain greater profits compared to the farm workers. Another goal is to fulfill daily needs. This is done by peasants because the work of farmworkers is no longer able to meet their daily needs.

\section{BIBLIOGRAPHY}

\section{Books:}

Firdausy, Carunia Mulya; 1995. Model dan Kebijakan Pengembangan Sektor Informal Pedagang Kaki Lima Pengembangan Sektor Informal Pedagang Kaki Lima di Perkotaan. Jakarta: Dewan Riset Nasional dan Bappenas bekerjasama dengan Puslitbang Ekonomi dan Pembangunan LIPI. Jakarta

Effendi, T.N. dan Manning, C; 1995. Sumber Daya Manusia, Peluang Kerja dan Kemiskinan: Tiara Wacana. Yogyakarta. Mason, Jennifer; 2002. Qualitative Researching: Sage Publications. London.

McMichael, Philip; 2008. Development and Social Change: A Global Perspective: Pine Forge Press. United States of America.

Moleong, Lexy J; 2006. Metode Penelitian Kualitatif: PT Remaja Rosdakarya. Bandung.
Mulyana, Deddy; 2001. Metodologi Penelitian Kualitatif: Paradigma Baru Ilmu Komunikasi dan Ilmu Sosial Lainnya. PT Remaja Rosda Karya. Bandung.

Nasution, Zulkarnain; 2009. Solidaritas Sosial dan Masyarakat Partisipasi Masyarakat Desa Transisi: UMM Press. Malang .

Poloma, Margaret M; 2007. Sosiologi Kontemporer: PT RajaGrafindo Persada. Jakarta.

Rakhmat, Jalaludin; 1998. Metode Penelitian Komunikasi. PT Remaja Rosda Karya. Bandung.

Ritzer, George \& Douglas J. Goodman; 2014. Teori Sosiologi Dari Teori Klasik Sampai Perkembangan Mutakhir Teori Sosial Postmodern: Kreasi Wacana. Bantul.

Rogers, Everett M; 1983. Diffusion of Innovations Third Edition: New York. The Free Press. 
Sanderson, Stephen K; 2000. Makro Sosiologi: PT RajaGrafindo Persada. Jakarta .

Smelser, Neil J, and Richard Swedberg; 2005. The Handbook of Economic Sociology Second Edition: Princeton University Press. United States of America.

Suryana, Achmad; Agus Pakpahan \& Achmad Djauhari; 1990. Diversifikasi Pertanian dalam Proses Mempercepat Laju Pembangunan Nasional: Pustaka Sinar Harapan. Jakarta .

Susilo, Rachmad K. Dwi; 2008. 20 Tokoh Sosiologi Modern: Ar-Ruzz Media. Jogjakarta .

Turner, Jonathan H; 1998. The Structure of Sociological Theory: Wadsworth Publishing Company. United States of America.

Wahyudi; 2005. Formasi dan Struktur Gerakan Sosial Petani: UMM Press. Malang .

Worsley, Peter; 1985. Modern Sociology Second Edition: Penguin Book. Great Britain.

Kota Batu Dalam Angka, 2017

Journal:

Jurnal Masyarakat, Kebudayaan dan Politik Tahun XIV Oktober 2001.

Jurnal Strategi Pemberdayaan Masyarakat Tahun 2010.

Jurnal Pemberdayaan Masyarakat Desa Dalam Pelaksanaan Program Desa Wisata Di Daerah Istimewa Yogyakarta Tahun 2012.

Jurnal Pendidikan Ilmu Sosial, Volume 22 Nomor 1 Tahun 2012.
Jurnal Pembangunan Wilayah dan Kota volume 8 Nomor 4 Tahun 2012.

Jurnal Manajemen dan Bisnis Volume 14 Nomor 02 Tahun 2014.

Jurnal Pesona Volume 18 Nomor 1 Tahun 2016.

Jurnal Forum Ilmu Sosial Volume 39 Nomor 1 Tahun 2012.

Jurnal Communication Volume 4 Nomor 2 Oktober 2013

\section{Online Books:} ; 2016. Produk Domestik Regional Bruto Kota Batu Menurut Lapangan Usaha Tahun 2011-2015: BPS Kota Batu. Batu

Dinas Pertanian dan Kehutanan Kota Batu; 2012. Rencana Strategis Dinas Pertanian dan KehutananKota Batu Tahun 2012-2017.

\section{Internet:}

batukota.bps.go.id: diakses pada tanggal 28 Desember 2016

http://regional.kompas.com/edisi 7 April 2011: diakses pada tanggal 6 Nopember 2015

http://www.simpuldemokrasi.com/titiktitik-kemiskinan-kota-batu-masihtinggi.html: diakses pada tanggal 20 Nopember 2014

https://m.tempo.co/read/news-desawisata-dikembangkan-di-batu: diakses pada tanggal 11 Agustus 2016

https://books.google.co.id/books?id: diakes pada tanggal 8 Maret 2017 